Review

\title{
What lies behind serum urate concentration? Insights from genetic and genomic studies
}

\author{
Kimiyoshi Ichida
}

Address: Tokyo University of Pharmacy and Life Science, 1432-1, Horinouchi Hachioji, Tokyo, 192-0392 Japan. Email: ichida@toyaku.ac.jp

\begin{abstract}
Many factors, including genetic components and acquired factors such as obesity and alcohol consumption, influence serum uric acid (urate) concentrations. Since serum urate concentrations are determined by the balance between renal urate excretion and the volume of urate produced via purine metabolism, urate transporter genes as well as genes coding for enzymes involved in purine metabolism affect serum urate concentrations. URAT1 was the first transporter affecting serum urate concentrations to be identified. Using the characterization of this transporter as an indicator, several transporters have been shown to transport urate, allowing the construction of a synoptic renal urate transport model. Notable re-absorptive urate transporters are URAT1 at apical membranes and GLUT9 at basolateral membranes, while ABCG2, MRP4 (multidrug resistance protein 4) and NPT1 are secretive transporters at apical membranes. Recent genome-wide association studies have led to validation of the in vitro model constructed from each functional analysis of urate transporters, and identification of novel candidate genes related to urate metabolism and transport proteins, such as glucokinase regulatory protein (GKRP), PDZK1 and MCT9. However, the function and physiologic roles of several candidates, as well as the influence of acquired factors such as obesity, foods, or alcoholic beverages, remain unclear.
\end{abstract}

\section{Introduction}

Hyperuricemia induces or facilitates gout, kidney stones, metabolic syndrome, hypertension and renal and cardiovascular disease, while exercise-induced acute renal failure is a significant complication of renal hypouricemia [1-3]. Although hyperuricemia has been more closely associated with gout and kidney stones, it has been recently recognized to be independently associated with components of metabolic syndrome, insulin resistance, hypertension, dyslipidemia and obesity. Metabolic syndrome is a clustering of cardiovascular disease risk factors and its prevalence is increasing. Several mechanisms for the association between hyperuricemia and metabolic syndrome have been proposed; insulin resistance leads to renal underexcretion of uric acid (urate); increased lactate in obesity accelerates renal urate reabsorption via urate transporter 1 (URAT1); fatty acid synthesis accelerates de novo purine synthesis via the pentose phosphate pathway, and so on [4]. Recent studies have shown that hyperuricemia independently causes atherosclerosis through urate-mediated inflammation and endothelial dysfunction, in addition to metabolic syndrome [5,6]. Thus, monitoring of serum urate concentrations in patients with hyperuricemia, kidney stones, metabolic syndrome, or renal or cardiovascular disease has been recommended, at least after a certain age.

Urate is the end product of human purine metabolism and is mainly excreted in urine. Serum urate concentrations are determined by the volume of urate produced via purine metabolism and by renal urate excretion. Many factors, including genetic components and acquired factors such as obesity and alcohol consumption, influence serum urate concentrations. Genetic links to serum urate concentrations have been identified, mainly from earlier studies of monogenic disorders, but have also been recently analyzed using genome-wide association approaches. Monogenic disorders such as hypoxanthine-guanine phosphoribosyl transferase deficiency (Lesch-Nyhan syndrome, MIM 300322), phosphoribosyl pyrophosphate synthetase overactivity, familial juvenile hyperuricemic nephropathy (MIM 162000) and glycogen storage disease are well known to induce hyperuricemia, while molybdenum cofactor deficiency (MIM 252150), xanthinuria (MIM 278300 and 603592), and renal hypouricemia (MIM 220150 and 612076) induce hypouricemia [7-15]. These diseases, with the exception of the renal disorders familial juvenile hyperuricemic nephropathy and renal hypouricemia, are classified as enzymatic deficiencies and have contributed to our understanding of purine metabolism. Uromodulin, also known as Tamm-Horsfall glycoprotein, was recently shown to cause the allelic disorders familial juvenile hyperuricemic nephropathy and medullary cystic kidney

ABCG2, ATP-binding cassette, sub-family G, member 2; $\alpha-K G$, a-ketoglutarate; CsA, cyclosporine A; ERM, ezrin-radixin-moesin; EST, expressed sequence tag; GAPDH, glyceraldehyde-3-phosphate dehydrogenase; GKRP, glucokinase regulatory protein; GLUT, glucose transporter; NHERF, $\mathrm{Na}^{+} / \mathrm{H}^{+}$exchanger regulatory factor; LRRC16A, leucine-rich repeat-containing protein 16A; MCT9, monocarboxylate transporter 9; MRP4, multidrug resistance protein 4; NPT1, sodium-dependent phosphate transport protein 1; OAT, organic anion transporter; $\mathrm{PAH}, \mathrm{p}$-aminohippurate; PPAR- $\alpha$, peroxisome proliferator-activated receptor- $\alpha$; SMCT, sodium-coupled monocarboxylate transporter; SNP, single nucleotide polymorphism; URAT1, urate transporter 1. 
disease 2, based on genetic linkage analyses, and the pathophysiology of these diseases has been clarified $[16,17]$. URAT1 was also recently identified as a homolog of organic anion transporter 1 and a transporter responsible for renal hypouricemia [18]. Using this finding as an indicator, several transporters have been shown to transport urate, leading to a better understanding of urate handling in the kidney. In recent years, genetic factors affecting serum urate concentrations have been identified by genome-wide association studies. Most genes indicated in these studies have been linked to urate transport; this is because most individuals tend to maintain renal urate excretion ability to some extent, which compensates for serum urate concentrations even under conditions of urate overproduction. This article reviews the major genes known to influence serum urate concentrations.

\section{Urate handling in the kidney}

In healthy males, the urate pool averages about $1,200 \mathrm{mg}$, with a mean turnover rate of $700 \mathrm{mg} /$ day. Under normal circumstances, two-thirds to three-quarters of daily urate disposal is excreted by the kidney. Urate reabsorption dominates over secretion in the kidney, resulting in the excretion of approximately $10 \%$ of its filtered load at the glomerulus. Non-protein-bound urate is freely filtered at the glomerulus. Urate is mainly reabsorbed in the proximal tubule in the kidney. The process of reabsorption of urate through proximal tubular cells is achieved via unidirectional transcellular transport, involving the uptake of urate into the cells from the proximal tubular fluid across the apical membrane, followed by excretion into the blood across the basolateral membrane. Secretion of urate through proximal tubular cells is achieved by the opposite route.

Until the last decade, renal handling of urate had been explained by a 'four-component model', which separated renal urate transport into glomerular filtration, presecretory reabsorption, secretion and postsecretory reabsorption. The concept of presecretory and postsecretory reabsorption was based on the hypothesis that the antiuricosuric effect of pyrazinamide was due to inhibition of urate secretion by pyrazinoate, the active metabolite of pyrazinamide. However, some reports using membrane vesicles have indicated that the anti-uricosuric effect of pyrazinamide results from enhanced urate reabsorption $[19,20]$.

\section{Recent genome-wide association studies for serum urate concentrations}

Candidate-gene association studies depend on current knowledge of a phenotype's suspected pathology to select single nucleotide polymorphisms (SNPs) to test for associations, while genome-wide association studies are essentially screening studies without prior biological hypotheses. Genome-wide association studies have the power to identify multiple new associations, although these require external validation and large sample sizes to achieve extremely small $P$-values. Recently, genome-wide association studies for serum urate concentrations have been performed [21-28]. In all of the studies, SNPs in SLC2A9, the glucose transporter gene family, were unexpectedly associated with serum urate concentrations. Similarly, several genes, including $A B C G 2$, encoding a multidrug resistance protein, have been identified.

\section{Major genes influence serum urate concentrations SLC22A12 (URAT1)}

URAT1, a member of the organic anion transporter (OAT) family, is encoded by $S L C 22 A 12$, and is expressed in the kidney. URAT1 was identified as a transporter for urate reabsorption in exchange for lactate at the apical membrane of the renal proximal tubular cell [18] (Figure 1). URAT1 mediates the exchange of urate for several organic anions and inorganic anions, such as lactate, pyrazinecarboxylic acid and chloride, and is cis-inhibited by probenecid, benzbromarone, losartan, and lactate [18]. Enomoto et al. [18] demonstrated that URAT1 regulates serum urate concentrations by showing that three patients with renal hypouricemia had defects in SLC22A12. Patients with this disorder demonstrate extremely low serum urate concentrations, mostly under $1.0 \mathrm{mg} / \mathrm{dl}$, because of increased urate excretion. This fact indicates that URAT1 is a major urate reabsorptive transporter and is a therapeutic target for the treatment of hyperuricaemia.

About 90\% of Japanese patients with renal hypouricemia exhibit a defect in URAT1 [3]. Renal hypouricemia is common in Japanese populations and possibly also in the non-Ashkenazi Jewish ethnic group. The high incidence of renal hypouricemia is a reflection of the high allele frequency (2.30 to $2.37 \%$ ) of the G774A mutation in SLC22A12 among Japanese [29,30]. This mutation was originally brought by immigrants from the Asian continent, and thereafter expanded in the Japanese population by founder effects [31].

\section{SLC2A9 (GLUT9)}

The putative function of glucose transporter (GLUT) 9 had been obscure, although GLUT9 (SLC2A9) was cloned as a member of the facilitated glucose transporter family, based on sequence similarity to GLUTs [32]. However, several genome-wide association studies have demonstrated a clear association of SNPs in SLC2A9 with serum urate concentrations [21,22,24-27,33].

GLUT9 is highly expressed in the kidney and liver. GLUT9L (long isoform) is localized to basolateral membranes in proximal tubule epithelial cells, while the splice variant GLUT9S (short isoform) localizes to apical membranes [34] (Figure 1). Vitart et al. [26] showed that GLUT9 transports urate and fructose, using a Xenopus 


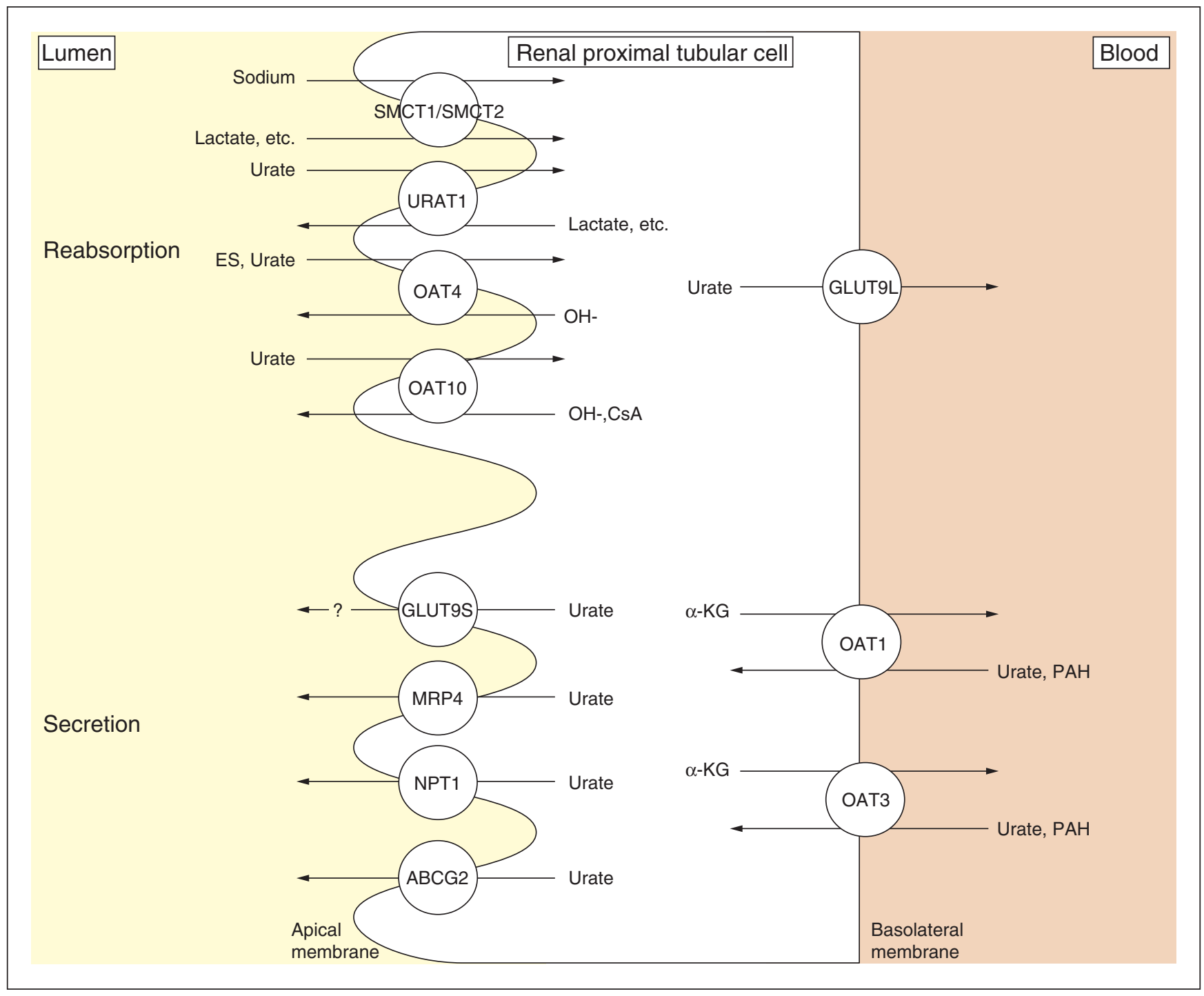

Figure 1

Urate transporters at the proximal tubule. Transporters responsible for urate reabsorption and secretion are illustrated $[18,21,43,48,52,77-80]$. Sodium-anion co-transporters SMCT1 and 2 at the apical membrane are included in this figure because SMCT transports lactate, the counterpart of urate. URAT1 is a main transporter for urate reabsorption in exchange for lactate at the apical membrane. URAT1 mediates the exchange of urate for several organic anions and inorganic anions. The long isoform of GLUT9 (GLUT9L) is localized to basolateral membranes in proximal tubule epithelial cells, while the short splice variant (GLUT9S) localizes to apical membranes. GLUT9L is a primary efflux transporter of intracellular urate to the interstitium/blood space. Abbreviations: ABCG2, ATP-binding cassette, sub-family G, member 2; $\alpha$-KG, a-ketoglutarate; CsA, cyclosporine A; ES, estrone sulfate; GLUT, glucose transporter; MRP4, multidrug resistance protein 4; NPT1, sodium-dependent phosphate transport protein 1; OAT, organic anion transporter; PAH, para-aminohippurate; SMCT, sodium-coupled monocarboxylate transporter; URAT1: urate transporter 1.

oocyte expression system. Anzai et al. [35] characterized GLUT9 in detail and reported that it did not stimulate any significant uptake of organic anionic substrates, such as para-aminohippurate (PAH), estrone sulfate or salicylate, or of substrates known to interact with URAT1, such as lactate, nicotinate, $\beta$-hydroxybutyrate, or salicylate, thereby suggesting a narrower substrate specificity than that of URAT1. Kinetic analysis indicates that GLUT9 is a high-capacity urate transporter and that extracellular glucose can accelerate urate efflux by GLUT9 [36]. The fact that GLUT9 deficiency resulted in renal hypouricemia shows GLUT9 to be an efflux transporter of intracellular urate from the tubular cell to the interstitium/blood space [37]. Efflux transport of urate at basolateral membranes appears to depend principally on GLUT9L. On the other hand, URAT1 mainly acts as an influx transporter for urate at 
apical membranes. Thus, GLUT9 deficiency would lead to hypouricemia because of decreased urate reabsorption, even if GLUT9S mediates efflux transport of urate at apical membranes.

Mice with systemic knockout of Glut9 display moderate hyperuricemia, massive hyperuricosuria, and an earlyonset obstructive nephropathy [38]. In contrast, liverspecific inactivation of the Glutg gene in mice leads to severe hyperuricemia and hyperuricosuria in the absence of urate nephropathy. Fractional excretion of urate in liverspecific Glut9 knockout mice was lower than that in systemic Glut9 knockout mice. These data and the absence of urate nephropathy in liver-specific Glut9 knockout mice suggest that the urate transport direction via Glut9 at apical membranes is reabsorptive in mice. The hyperuricemia in systemic and liver-specific Glut9 knockout mice indicates that urate cannot be converted to allantoin in the absence of liver Glut9; this demonstrates that hepatocytes take up urate via Glut9 at basolateral membranes. However, the physiological role for GLUT9S at renal apical membranes and for GLUT9 in hepatocytes in humans has not yet been defined.

Furthermore, GLUT9 is thought to act as a common transporter mediating urate metabolism and glucose and fructose metabolism, since both diabetes mellitus and high fructose intake influence serum urate concentrations. Further research into this relationship and the role of GLUT9 in diabetes and metabolic syndrome may lead to the development of effective prevention and treatment of these diseases.

\section{ABCG2}

ATP-binding cassette, sub-family G, member 2 (ABCG2) is a half-transporter and most likely functions as a homodimer. ABCG2 was cloned in a project to characterize all human ATP-binding cassette superfamily genes [39]. First identified as a multidrug resistance protein, ABCG2 has a wide range of substrates, such as mitoxantrone, topotecan, rhodamine 123, methotrexate, estrone-3-sulfate, and porphyrins [40]. ABCG2 is expressed in the plasma membranes of a variety of tissues, including placenta, pharynx, bladder, brain, and intestine, and mediates the efflux of xenobiotics. In the kidney, $\mathrm{ABCG} 2$ is expressed at the apical membrane of the proximal tubule [41] (Figure 1). Although ABCG2 was identified pathophysiologically as a gene partially responsible for porphyria, ABCG2's role in vivo remains unclear [42].

In genome-wide association studies, SNPs in $A B C G 2$ have been found to be related to serum urate concentrations [23,27]. The ability of ABCG2 to transport urate was recently confirmed by measuring urate efflux from ABCG2expressing Xenopus oocytes [43]. It would follow, therefore, that ABCG2 would excrete urate at the renal proximal tubule apical membrane. The frequency of the mutation Q141K, encoded by the common SNP rs2231142, is highly variable in the human population; the frequency of the A allele ranges from 1 to $5 \%$ in Africans, to approximately $30 \%$ in Asians. Urate transport by the ABCG2 mutant Q141K is about half that of the wild type [43]. Q126X shows stronger effects on gout development than Q141K, conferring an odds ratio of 5.97 [44]. Furthermore, 10\% of patients with gout had genotype combinations resulting in more than $75 \%$ reduction of $\mathrm{ABCG} 2$ function (odds ratio 25.8). These findings indicate that non-functional variants of ABCG2 essentially block gut and renal urate excretion and cause gout.

\section{SLC22A11 (OAT4)}

OAT4 encoded by SLC22A11 is expressed in the kidney and placenta at moderate levels [45]. OAT4 is localized to the apical membrane of proximal tubular cells in the kidney (Figure 1). OAT4 exhibits 53\% amino acid homology with URAT1. OAT4 functions as an organic anion/dicarboxylate exchanger and is responsible for the reabsorption of organic anions driven by an outwardly directed dicarboxylate gradient [46]. Substrates for OAT4 include sulfate conjugates such as estrone sulfate and dehydroepiandrosterone sulfate, prostaglandins $\mathrm{E}_{2}$ and $\mathrm{F}_{2 \mathrm{a}}$, and urate $[45,47,48]$. Since OAT4 is thought to be an asymmetric carrier, it may transport organic anions such as glutarate and p-aminohippurate outward into the lumen and act as an entry route for urate and estrone sulfate into the proximal tubule cell. Probenecid inhibits $\mathrm{OAT}_{4}$ with $K_{\mathrm{i}}$ values of approximately $50 \mu \mathrm{M}$, which would be sufficient to decrease urate reabsorption by $\mathrm{OAT}_{4}[49,50]$.

Hagos et al. [48] reported OAT4 to be a low-affinity urate transporter, using cells stably expressing $\mathrm{OAT}_{4}$ and $\mathrm{OAT}_{4}$ expressing oocytes in plasma-equivalent concentrations (up to $400 \mu \mathrm{M}$ ). The contribution of OAT4 to urate transport at the apical membrane of proximal tubular cells under physiological conditions is unclear; however, genome-wide association studies have reported an association between $\mathrm{OAT}_{4}$ and serum urate concentrations [27]. Thus, OAT4 may share with URAT1 the physiologic function of urate reabsorption at the apical membrane.

\section{SLC17A1 (NPT1), SLC17A 3 and SLC17A4}

Meta-analysis of genome-wide association studies showed that a region mapped to chromosome 6p23-p21.3, including the SLC17A1, SLC17A3, and SLC17A4 genes, is associated with serum urate concentrations [27]. Renal sodium-dependent phosphate transport protein 1 (NPT1) is encoded by SLC17A1 [51]. NPT1, which was first cloned as a phosphate transporter, is located in the proximal convoluted renal tubule (Figure 1). NPT1 mediates voltagesensitive transport of organic anions, including urate, and is suggested to function as a urate secretor [52]. In SNP analysis of NPT1 in patients with gout, the $\mathrm{T}$ allele 


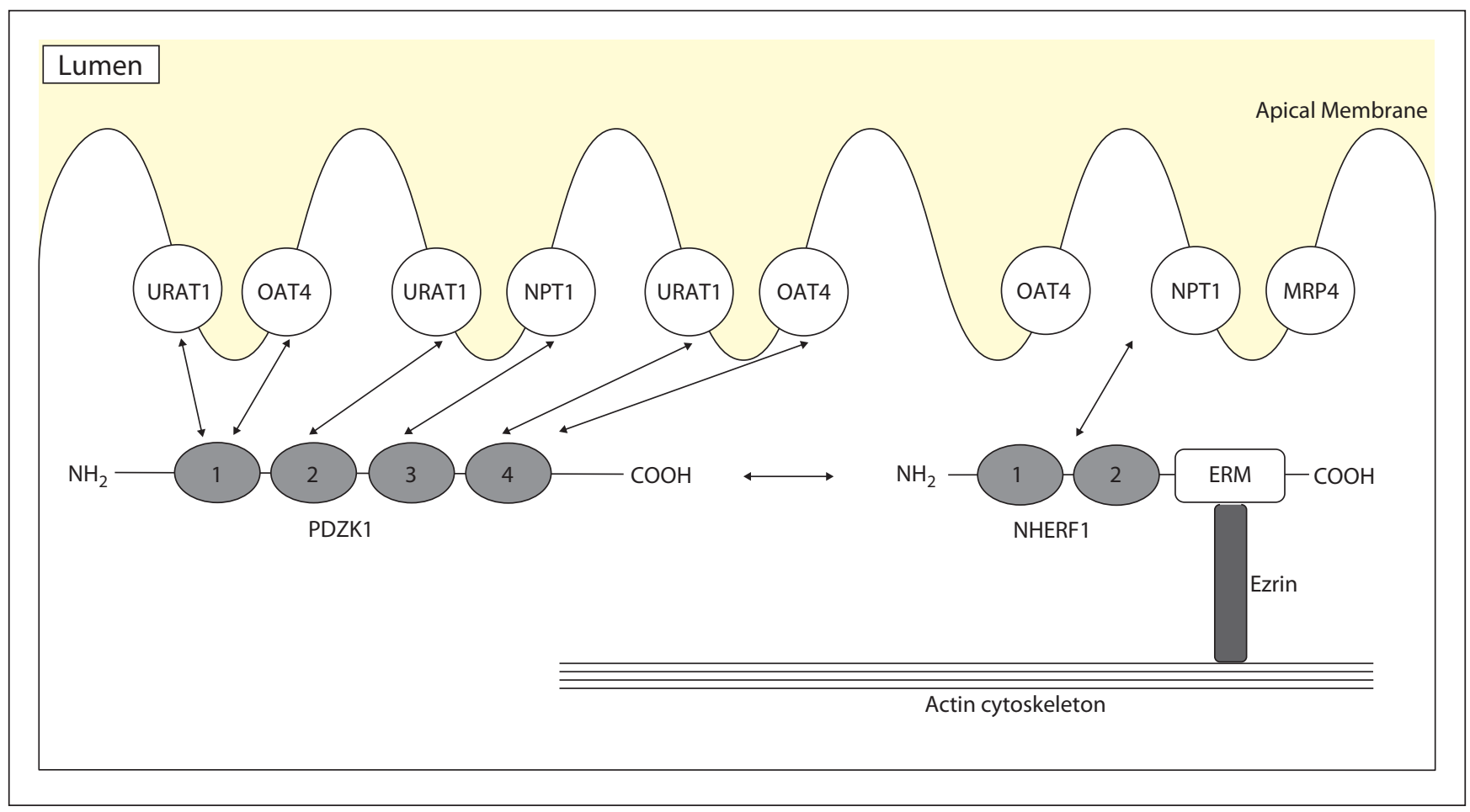

Figure 2

Schematic representation of the interaction between PDZ proteins and urate transporters at the apical membrane of the proximal tubule. PDZK1 binds another PDZ protein, $\mathrm{Na}^{+} / \mathrm{H}^{+}$exchanger regulatory factor 1 (NHERF1). NHERF1 contains two tandem PDZ domains and a carboxy-terminal domain that binds members of the ERM (ezrin-radixin-moesin) family of membrane-cytoskeletal adaptors. The carboxyl terminus of URAT1, OAT4, and NPT1 binds with PDZK1 [81]. URAT1 interacts with PDZK1 via PDZ domains 1, 2, and 4, while OAT4 interacts with PDZ domains 1 and $4[56,57]$. OAT4, NPT1, and MRP4 also bind NHERF1 $[82,83]$. Abbreviations: MRP4, multidrug resistance protein 4; NHERF, $\mathrm{Na}^{+} / \mathrm{H}^{+}$exchanger regulatory factor; NPT1, sodium-dependent phosphate transport protein 1; OAT, organic anion transporter; URAT1, urate transporter 1.

frequency of rs1165196 (T806C) was significantly higher in patients than in control individuals and T806C showed significant association with reduced serum urate concentrations in obese individuals in spite of a negative association in all controls [53]. However, the precise mechanisms at a molecular level remain to be clarified.

$\mathrm{NPT}_{4}$, encoded by $\mathrm{SLC}_{17} \mathrm{~A}_{3}$, is expressed in the kidney, brain, and liver, while a sodium/phosphate co-transporter encoded by $S L C 17 A 4$ is expressed in the intestine, bladder, and liver, and weakly in the kidney and testis. NPT4's biological function has not been clarified in detail, and although a heterozygous transition of $\mathrm{NPT}_{4}$ in a patient with glycogen storage disease type Ic has been reported, a causal relationship has not been established [54].

\section{PDZK1}

PDZK1, coding for PDZ domain containing 1 , acts as a scaffolding protein for a large variety of transporter and regulatory proteins and has been identified in the kidney, liver, small intestine, and adrenal cortex [55]. Within the kidney, PDZK1 is localized in the apical membrane of the proximal tubule. PDZK1 contains four PDZ-binding domains, each of which binds independently a sequencespecific PDZ motif at the carboxy-terminal end of transporters (Figure 2). PDZ domains are thought to play important roles in targeting of proteins to specific cell membranes, assembling proteins into signaling complexes for efficient transduction, and regulating the function of transporters. The urate transporters URAT1, OAT4, and NPT1 interact with PDZK1 via a class I PDZ motif (-S/T-X$\Phi$, where $\mathrm{X}$ is any amino acid and $\Phi$ is a hydrophobic amino acid) [55-58]. Coexpression of URAT1 or OAT4 and PDZK1 in HEK293 cells increases transport activity through increasing cell-surface expression of the transporters. This effect is suggested to result from stabilization and/or anchoring of URAT1 and OAT4 at the cell membrane by PDZK1. PDZK1 may also provide a structural basis for functional coupling of transporters. For example, binding of both URAT1 and sodium-coupled monocarboxylate transporter (SMCT) to PDZK1 may induce efficient substrate transport because monocarboxylates such as lactate, pyruvate, $\beta$-hydroxybutyrate and acetoacetate are substrates for SMCT; thus, an outwardly directed gradient 


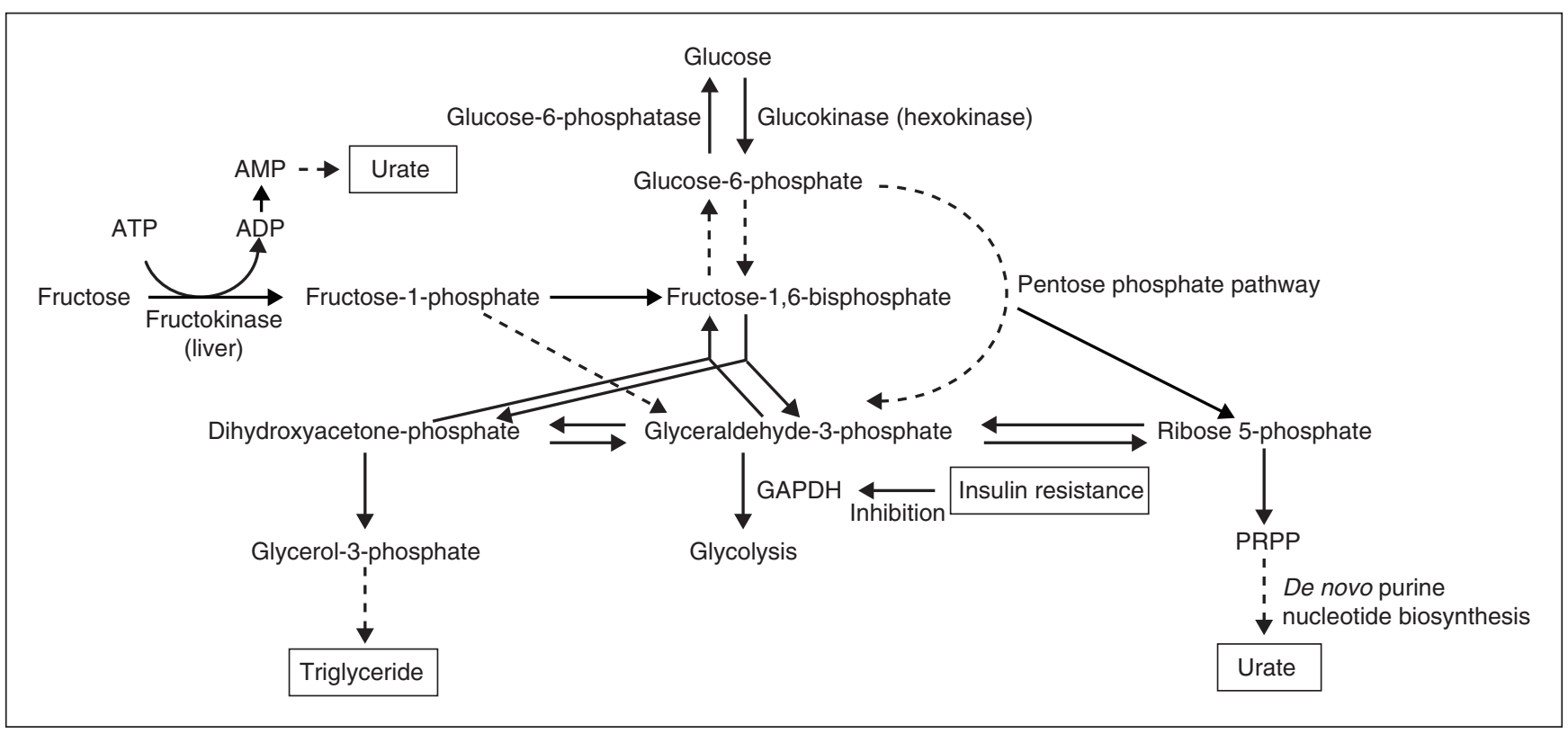

Figure 3

Relationships between purine, fructose, and glucose metabolism. Abbreviations: GAPDH, glyceraldehyde-3-phosphate dehydrogenase; PRPP, phosphoribosyl pyrophosphate.

of these monocarboxylates created by the sodium-coupled uptake by SMCT drives URAT1-mediated urate reabsorption [56,59-62]. Consequently, SNPs and some mutations of PDZK1 would influence serum urate concentrations.

Fibrates, the peroxisome proliferator-activated receptor- $\alpha$ (PPAR- $\alpha$ ) agonists, decrease hepatic levels of PDZK1 in a PPAR- $\alpha$-dependent fashion in mouse liver, while PPAR- $\alpha$ upregulates the expression of PDZK1 in humans $[63,64]$. PPAR- $\alpha$, which belongs to the nuclear receptor superfamily and regulates the expression of genes responsible for fatty acid $\beta$-oxidation and energy homeostasis, is one of the key molecules involved in metabolic disorders. Regulation of PDZK1 expression by PPAR- $\alpha$ has not been fully clarified, and it is difficult to explain the induction of renal urate underexcretion in obesity on the basis of human PDZK1 upregulation by PPAR- $\alpha$. However, further elucidation of the relationship between PDZK1 and PPAR- $\alpha$ would help determine the role of PDZK1 in metabolic disorders.

\section{SLC16A9 (MCT9)}

SLC16A9, encoding monocarboxylate transporter 9 (MCT9), was identified purely from analysis of human genomic expressed sequence tag (EST) databases [65]. MCT9 is expressed in the parathyroid, kidney, trachea, spleen and adrenal gland. Meta-analysis of genome-wide association studies showed a relationship between SLC16A9 and serum urate concentrations, but the function of MCT9 remains unknown.

\section{LRRC16A (CARMIL) and SCGN}

Meta-analysis of genome-wide association studies showed a region containing the genes leucine-rich repeatcontaining protein 16A (LRRC16A) and SCGN, chromosomal locus 6p22.2, as a region associated with serum urate concentrations. However, the mechanism of their involvement remains elusive. CARMIL, encoded by LRRC16A, is important for actin-based motility and can bind to actin capping protein, an essential element of the actin cytoskeleton. Actin capping protein regulates polymerization by binding to the barbed ends of actin filaments. CARMIL inhibits the binding ability of actin capping protein and regulates its interaction with actin filaments. SCGN, coding for Secretagogin, a calciumbinding protein, is expressed in neuroendocrine tissue and pancreatic beta-cells. The function of Secretagogin is unknown, but it has been suggested to influence calcium influx, insulin secretion and proliferation in $\beta$-cells [66].

\section{GKRP}

Glucokinase, expressed exclusively in liver and pancreatic $\beta$-cells, plays an essential role in glucose metabolism by catalyzing the phosphorylation of glucose (Figure 3). Glucokinase regulatory protein (GKRP) acts as a competitive inhibitor as well as a nuclear-binding protein for glucokinase. Glucokinase is located in the nucleus, bound to GKRP as an inactive complex under basal glucose conditions. In high-glucose conditions, most studies have suggested that GKRP releases glucokinase, which is 
translocated into the cytoplasm and catalyzes the phosphorylation of glucose $[67,68]$. SNPs in GKRP are associated with increased triglyceride concentrations, lowered insulin resistance, and lower fasting glucose concentrations, protecting against the development of type 2 diabetes [69-71].

Hyperuricemia has been reported to be associated with the metabolic syndrome based on insulin resistance and hyperinsulinemia, since insulin decreases renal urate clearance [4,72]. Another hypothesized mechanism for hyperuricemia due to insulin resistance is that adenine nucleotide translocator inhibition by increased intracellular long-chain fatty acyl-CoA ester in insulinresistant states leads to high cytosolic AMP concentrations; this results in hyperuricemia by a high rate of breakdown to urate [73]. Insulin resistance may mediate the association of hyperuricemia with GKRP, as identified by a genome-wide association analysis [27].

\section{Clinical implications of genetic and genomic data}

Among the disorders associated with hyperuricemia or hypouricemia, gout is the most common disease, and its incidence is increasing. Hyperuricemia is classified into urate overproduction type, underexcretion type, and mixed type. Antihyperuricemic agents include xanthine dihydrogenase inhibitor and uricosuric agent. Japanese guidelines for management of gout recommend the use of xanthine dihydrogenase inhibitor for overproduction-type hyperuricemia, and uricosuric agent for underexcretion-type hyperuricemia [74]. Uricosuric agents, however, need to maintain a high urinary output or alkalinization of urine for prevention of urolithiasis. Furthermore, the indication of benzbromarone, a main uricosuric agent, has been controversial because of rare but serious hepatotoxicity. Thus, uricosuric agents have been regarded as a secondline agent of the xanthine dihydrogenase inhibitor [75,76]. However, urate excretion is the major factor in the regulation of serum urate concentrations, supported by the results of genome-wide association studies. Recently, identified molecules such as GLUT9 and ABCG2 should be candidates for targeting the development of new antihyperuricemic agents.

\section{Conclusions}

Recent progress in the study of renal urate transport has identified transporters for urate reabsorption and secretion at apical and basolateral membranes. The extent of the contribution of some transporters such as URAT1 and GLUT9 to urate transport has also been clarified, and a synoptic renal urate transport model has been developed.

Genome-wide association studies have led to verification of the model and the identification of novel candidate genes related to urate metabolism and transport. Most candidates have been categorized as transporters. These results are consistent with the fact that about $90 \%$ of hyperuricemic patients suffer from underexcretion-type hyperuricemia. However, functional and physiological roles of several candidates are as yet uncertain, and the influence of acquired factors, including obesity, diet or alcoholic beverages, also requires further investigation.

Future research should elucidate the urate transport systems in the liver and intestine, since hepatocytes are major contributors to purine metabolism and about onethird of daily urate disposal is excreted into the intestine. The mechanism of overproductive hyperuricemia should also be established.

\section{Competing interests}

The author declares that he has no competing interests.

\section{Acknowledgements}

I thank M Hosoyamada for suggestions and critical reading of the manuscript.

This work was supported in part by grants from Grants-in-Aid for Scientific Research from the Japan Society for the Promotion of Science, and a grant from the Gout Research Foundation of Japan.

\section{References}

1. Edwards NL: The role of hyperuricemia in vascular disorders. Curr Opin Rheumatol 2009, 21:132-137.

2. Schachter M: Uric acid and hypertension. Curr Pharm Des 2005, 11:4139-4143.

3. Ichida K, Hosoyamada M, Hisatome I, Enomoto A, Hikita M, Endou $\mathrm{H}$, Hosoya $\mathrm{T}$ : Clinical and molecular analysis of patients with renal hypouricemia in Japan-influence of URAT1 gene on urinary urate excretion. J Am Soc Nephrol 2004, 15:164-173.

4. Facchini F, Chen YD, Hollenbeck CB, Reaven GM: Relationship between resistance to insulin-mediated glucose uptake, urinary uric acid clearance, and plasma uric acid concentration. JAMA 1991, 266:3008-3011.

5. Johnson RJ, Kang DH, Feig D, Kivlighn S, Kanellis J, Watanabe S, Tuttle KR, Rodriguez-Iturbe B, Herrera-Acosta J, Mazzali $M$ : Is there a pathogenetic role for uric acid in hypertension and cardiovascular and renal disease? Hypertension 2003, 41:1183-1190.

6. Kanellis J, Kang DH: Uric acid as a mediator of endothelial dysfunction, inflammation, and vascular disease. Semin Nephrol 2005, 25:39-42.

7. OMIM: Lesch-Nyhan Syndrome [http://www.ncbi.nlm.nih.gov/ entrez/dispomim.cgi?id=300322] (accessed 11 November 2009).

8. OMIM: Hyperuricemic nephropathy, familial juvenile 1; HNFJ1 [http://www.ncbi.nlm.nih.gov/entrez/dispomim.cgi?id=162000] (accessed 11 November 2009).

9. OMIM: Molybdenum Cofactor Deficiency [http://www.ncbi. nlm.nih.gov/entrez/dispomim.cgi?id=252150] (accessed 11 November 2009).

10. Ichida K, Amaya Y, Kamatani N, Nishino T, Hosoya T, Sakai O: Identification of two mutations in human xanthine dehydrogenase gene responsible for classical type I xanthinuria. J Clin Invest 1997, 99:2391-2397.

11. Ichida K, Matsumura T, Sakuma R, Hosoya T, Nishino T: Mutation of human molybdenum cofactor sulfurase gene is responsible for classical xanthinuria type II. Biochem Biophys Res Commun 2001, 282:1194-1200. 
12. OMIM: Xanthinuria type I [http://www.ncbi.nlm.nih.gov/entrez/ dispomim.cgi?id=278300] (accessed 11 November 2009).

13. OMIM: Xanthinuria type II [http://www.ncbi.nlm.nih.gov/entrez/ dispomim.cgi?id=603592] (accessed 11 November 2009).

14. OMIM: Hypouricemuia, renal, 1, RHUC1 [http://www.ncbi. nlm.nih.gov/entrez/dispomim.cgi?id=220150] (accessed 11 November 2009).

15. OMIM: Hypouricemuia, renal, 2, RHUC2 [http://www.ncbi. $\mathrm{nlm}$.nih.gov/entrez/dispomim.cgi?id=612076] (accessed 11 November 2009).

16. Hart TC, Gorry MC, Hart PS, Woodard AS, Shihabi Z, Sandhu J, Shirts B, Xu L, Zhu H, Barmada MM, Bleyer AJ: Mutations of the UMOD gene are responsible for medullary cystic kidney disease 2 and familial juvenile hyperuricaemic nephropathy. J Med Genet 2002, 39:882-892.

17. Rampoldi L, Caridi G, Santon D, Boaretto F, Bernascone I, Lamorte G, Tardanico R, Dagnino M, Colussi G, Scolari F, Ghiggeri GM, Amoroso A, Casari G: Allelism of MCKD, FJHN and GCKD caused by impairment of uromodulin export dynamics. Hum Mol Genet 2003, 12:3369-3384.

18. Enomoto A, Kimura $H$, Chairoungdua A, Shigeta $Y$, Jutabha $P$, Cha SH, Hosoyamada M, Takeda M, Sekine T, Igarashi T, Matsuo H, Kikuchi Y, Oda T, Ichida K, Hosoya T, Shimokata K, Niwa T, Kanai Y, Endou H: Molecular identification of a renal urate anion exchanger that regulates blood urate levels. Nature 2002, 417:447-452.

19. Guggino SE, Aronson PS: Paradoxical effects of pyrazinoate and nicotinate on urate transport in dog renal microvillus membranes. J Clin Invest 1985, 76:543-547.

20. Roch-Ramel F, Guisan B, Diezi J: Effects of uricosuric and antiuricosuric agents on urate transport in human brushborder membrane vesicles. J Pharmacol Exp Ther 1997, 280:839-845.

21. Li S, Sanna S, Maschio A, Busonero F, Usala G, Mulas A, Lai $S$, Dei M, Orru M, Albai G, Bandinelli $S$, Schlessinger D, Lakatta E, Scuteri A, Najjar SS, Guralnik J, Naitza S, Crisponi L, Cao A, Abecasis G, Ferrucci L, Uda M, Chen WM, Nagaraja $R$ : The GLUT9 gene is associated with serum uric acid levels in Sardinia and Chianti cohorts. PLoS Genet 2007, 3: e194.

22. Wallace C, Newhouse SJ, Braund P, Zhang F, Tobin M, Falchi M, Ahmadi K, Dobson RJ, Marcano AC, Hajat C, Burton P, Deloukas P, Brown M, Connell JM, Dominiczak A, Lathrop GM, Webster J, Farrall M, Spector T, Samani NJ, Caulfield MJ, Munroe PB: Genome-wide association study identifies genes for biomarkers of cardiovascular disease: serum urate and dyslipidemia. Am J Hum Genet 2008, 82:139-149.

23. Dehghan A, Kottgen A, Yang Q, Hwang SJ, Kao WL, Rivadeneira F, Boerwinkle E, Levy D, Hofman A, Astor BC, Benjamin EJ, van Duijn CM, Witteman JC, Coresh J, Fox CS: Association of three genetic loci with uric acid concentration and risk of gout: a genome-wide association study. Lancet 2008, 372:1953-1961.

24. Doring A, Gieger C, Mehta D, Gohlke H, Prokisch H, Coassin S, Fischer G, Henke K, Klopp N, Kronenberg F, Paulweber B, Pfeufer A, Rosskopf D, Volzke H, Illig T, Meitinger T, Wichmann HE, Meisinger C: SLC2A9 influences uric acid concentrations with pronounced sex-specific effects. Nat Genet 2008, 40:430-436.

25. McArdle PF, Parsa A, Chang YP, Weir MR, O'Connell JR, Mitchell BD, Shuldiner AR: Association of a common nonsynonymous variant in GLUT9 with serum uric acid levels in old order amish. Arthritis Rheum 2008, 58:2874-2881.

26. Vitart V, Rudan I, Hayward C, Gray NK, Floyd J, Palmer CN, Knott SA, Kolcic I, Polasek O, Graessler J, Wilson JF, Marinaki A, Riches PL, Shu X, Janicijevic B, Smolej-Narancic N, Gorgoni B, Morgan J, Campbell S, Biloglav Z, Barac-Lauc L, Pericic M, Klaric IM, Zgaga L, Skaric-Juric T, Wild SH, Richardson WA, Hohenstein P, Kimber CH, Tenesa A, et al.: SLC2A9 is a newly identified urate transporter influencing serum urate concentration, urate excretion and gout. Nat Genet 2008, 40: 437-442.
27. Kolz M, Johnson T, Sanna S, Teumer A, Vitart V, Perola $M$ Mangino $M$, Albrecht $E$, Wallace $C$, Farrall $M$, Johansson $A$, Nyholt DR, Aulchenko Y, Beckmann JS, Bergmann S, Bochud M, Brown M, Campbell H, Connell J, Dominiczak A, Homuth G, Lamina C, McCarthy Ml, Meitinger T, Mooser V, Munroe P, Nauck M, Peden J, Prokisch H, Salo P, et al.: Meta-analysis of 28,141 individuals identifies common variants within five new loci that influence uric acid concentrations. PLOS Genet 2009, 5:e1000504.

28. Zemunik T, Boban M, Lauc G, Jankovic S, Rotim K, Vatavuk Z, Bencic G, Dogas Z, Boraska V, Torlak V, Susac J, Zobic I, Rudan D, Pulanic D, Modun D, Mudnic I, Gunjaca G, Budimir $D$, Hayward C, Vitart V, Wright AF, Campbell H, Rudan I: Genome-wide association study of biochemical traits in Korcula Island, Croatia. Croat Med J 2009, 50:23-33.

29. Iwai N, Mino Y, Hosoyamada M, Tago N, Kokubo Y, Endou H: A high prevalence of renal hypouricemia caused by inactive SLC22A12 in Japanese. Kidney Int 2004, 66:935-944.

30. Taniguchi A, Urano W, Yamanaka M, Yamanaka $H$, Hosoyamada M, Endou $\mathrm{H}$, Kamatani $\mathrm{N}$ : A common mutation in an organic anion transporter gene, SLC22A12, is a suppressing factor for the development of gout. Arthritis Rheum 2005, 52:2576-2577.

31. Ichida K, Hosoyamada M, Kamatani N, Kamitsuji S, Hisatome I, Shibasaki T, Hosoya T: Age and origin of the G774A mutation in SLC22A12 causing renal hypouricemia in Japanese. Clin Genet 2008, 74:243-251.

32. Phay JE, Hussain HB, Moley JF: Cloning and expression analysis of a novel member of the facilitative glucose transporter family, SLC2A9 (GLUT9). Genomics 2000, 66: 217-220.

33. Stark K, Reinhard W, Neureuther K, Wiedmann S, Sedlacek K, Baessler A, Fischer M, Weber S, Kaess B, Erdmann J, Schunkert H, Hengstenberg C: Association of common polymorphisms in GLUT9 gene with gout but not with coronary artery disease in a large case-control study. PLOS One 2008, 3:e1948.

34. Augustin R, Carayannopoulos MO, Dowd LO, Phay JE, Moley $\mathrm{JF}$, Moley $\mathrm{KH}$ : Identification and characterization of human glucose transporter-like protein-9 (GLUT9): alternative splicing alters trafficking. J Biol Chem 2004, 279:1622916236.

35. Anzai N, Ichida K, Jutabha P, Kimura T, Babu E, Jin CJ, Srivastava S, Kitamura K, Hisatome I, Endou H, Sakurai $\mathrm{H}$ : Plasma urate level is directly regulated by a voltage-driven urate efflux transporter URATV1 (SLC2A9) in humans. $J$ Biol Chem 2008, 283:26834-26838.

36. Caulfield MJ, Munroe PB, O'Neill D, Witkowska K, Charchar FJ, Doblado M, Evans S, Eyheramendy S, Onipinla A, Howard P, Shaw-Hawkins S, Dobson RJ, Wallace C, Newhouse SJ, Brown M, Connell JM, Dominiczak A, Farrall M, Lathrop GM, Samani NJ, Kumari M, Marmot M, Brunner E, Chambers J, Elliott P, Kooner J, Laan M, Org E, Veldre G, Viigimaa M, et al.: SLC2A9 is a high-capacity urate transporter in humans. PLoS Med 2008, 5:e197.

37. Matsuo H, Chiba T, Nagamori S, Nakayama A, Domoto $H$, Phetdee K, Wiriyasermkul P, Kikuchi Y, Oda T, Nishiyama J, Nakamura T, Morimoto Y, Kamakura K, Sakurai Y, Nonoyama $\mathrm{S}$, Kanai $\mathrm{Y}$, Shinomiya N: Mutations in glucose transporter 9 gene SLC2A9 cause renal hypouricemia. Am J Hum Genet 2008, 83:744-751.

38. Preitner F, Bonny O, Laverriere A, Rotman S, Firsov D, Da Costa A, Metref S, Thorens B: Glut9 is a major regulator of urate homeostasis and its genetic inactivation induces hyperuricosuria and urate nephropathy. Proc Natl Acad Sci U S A 2009, 106:15501-15506.

39. Allikmets R, Schriml LM, Hutchinson A, Romano-Spica V, Dean $M$ : A human placenta-specific ATP-binding cassette gene (ABCP) on chromosome $4 \mathrm{q} 22$ that is involved in multidrug resistance. Cancer Res 1998, 58:5337-5339.

40. Mao $Q$, Unadkat JD: Role of the breast cancer resistance protein (ABCG2) in drug transport. AAPS J 2005, 7:E118133. 
41. Huls M, Brown CD, Windass AS, Sayer R, van den Heuvel JJ, Heemskerk S, Russel FG, Masereeuw R: The breast cancer resistance protein transporter ABCG2 is expressed in the human kidney proximal tubule apical membrane. Kidney Int 2008, 73:220-225.

42. Jonker JW, Buitelaar $M$, Wagenaar $E$, Van Der Valk MA, Scheffer GL, Scheper RJ, Plosch T, Kuipers F, Elferink RP, Rosing $\mathrm{H}$, Beijnen JH, Schinkel AH: The breast cancer resistance protein protects against a major chlorophyll-derived dietary phototoxin and protoporphyria. Proc Natl Acad Sci U S A 2002, 99:15649-15654.

43. Woodward OM, Kottgen A, Coresh J, Boerwinkle E, Guggino WB, Kottgen M: Identification of a urate transporter, ABCG2, with a common functional polymorphism causing gout. Proc Natl Acad Sci U S A 2009, 106:10338-10342.

44. Matsuo $H$, Takada $T$, Ichida $K$, Nakamura $T$, Nakayama $A$, Ikebuchi Y, Ito K, Kusanagi Y, Chiba T, Tadokoro S, Takada Y, Oikawa Y, Inoue H, Suzuki K, Okada R, Nishiyama J, Domoto $H$, Watanabe $S$, Fujita $M$, Morimoto $Y$, Naito $M$, Nishio $K$, Hishida A, Wakai K, Asai Y, Niwa K, Kamakura K, Nonoyama S, Sakurai Y, Hosoya T, et al.: Common defects of ABCG2, a high-capacity urate exporter, cause gout: a function-based genetic analysis in a Japanese population. Science Translational Medicine 2009, 1:5ra11.

45. Cha SH, Sekine T, Kusuhara H, Yu E, Kim JY, Kim DK, Sugiyama $\mathrm{Y}$, Kanai $\mathrm{Y}$, Endou $\mathrm{H}$ : Molecular cloning and characterization of multispecific organic anion transporter 4 expressed in the placenta. J Biol Chem 2000, 275:45074512.

46. Ekaratanawong S, Anzai N, Jutabha P, Miyazaki H, Noshiro R, Takeda M, Kanai Y, Sophasan S, Endou H: Human organic anion transporter 4 is a renal apical organic anion/dicarboxylate exchanger in the proximal tubules. J Pharmacol Sci 2004, 94:297-304.

47. Kimura H, Takeda M, Narikawa S, Enomoto A, Ichida K, Endou $\mathrm{H}$ : Human organic anion transporters and human organic cation transporters mediate renal transport of prostaglandins. J Pharmacol Exp Ther 2002, 301:293-298.

48. Hagos $Y$, Stein D, Ugele B, Burckhardt G, Bahn A: Human renal organic anion transporter 4 operates as an asymmetric urate transporter. J Am Soc Nephrol 2007, 18:430-439.

49. Enomoto A, Takeda M, Shimoda M, Narikawa S, Kobayashi Y, Yamamoto T, Sekine T, Cha SH, Niwa T, Endou H: Interaction of human organic anion transporters 2 and 4 with organic anion transport inhibitors. J Pharmacol Exp Ther 2002, 301: 797-802.

50. Hashimoto T, Narikawa S, Huang XL, Minematsu T, Usui T, Kamimura $\mathrm{H}$, Endou $\mathrm{H}$ : Characterization of the renal tubular transport of zonampanel, a novel alpha-amino-3-hydroxy5-methylisoxazole-4-propionic acid receptor antagonist, by human organic anion transporters. Drug Metab Dispos 2004, 32:1096-1102.

51. Chong SS, Kristjansson K, Zoghbi HY, Hughes MR: Molecular cloning of the cDNA encoding a human renal sodium phosphate transport protein and its assignment to chromosome 6p21.3-p23. Genomics 1993, 18:355-359.

52. Uchino H, Tamai I, Yamashita K, Minemoto Y, Sai Y, Yabuuchi $\mathrm{H}$, Miyamoto K, Takeda E, Tsuji A: p-aminohippuric acid transport at renal apical membrane mediated by human inorganic phosphate transporter NPT1. Biochem Biophys Res Commun 2000, 270:254-259.

53. Urano W, Taniguchi A, Anzai N, Inoue E, Kanai Y, Yamanaka M, Kamatani N, Endou H, Yamanaka H: Sodium-dependent phosphate cotransporter type 1 (NPT1) sequence polymorphisms in male patients with gout. Ann Rheum Dis 2009 [Epub ahead of print].

54. Melis D, Havelaar AC, Verbeek E, Smit GP, Benedetti A, Mancini GM, Verheijen F: NPT4, a new microsomal phosphate transporter: mutation analysis in glycogen storage disease type Ic. J Inherit Metab Dis 2004, 27:725-733.

55. Kocher O, Comella N, Tognazzi K, Brown LF: Identification and partial characterization of PDZK1: a novel protein containing PDZ interaction domains. Lab Invest 1998, 78:117125.
56. Anzai N, Miyazaki H, Noshiro R, Khamdang S, Chairoungdua A, Shin HJ, Enomoto A, Sakamoto S, Hirata T, Tomita K, Kanai $Y$, Endou $\mathrm{H}$ : The multivalent PDZ domain-containing protein PDZK1 regulates transport activity of renal urate-anion exchanger URAT1 via its C terminus. J Biol Chem 2004 279:45942-45950.

57. Miyazaki H, Anzai N, Ekaratanawong S, Sakata T, Shin HJ, Jutabha P, Hirata T, He X, Nonoguchi H, Tomita K, Kanai Y, Endou $\mathrm{H}$ : Modulation of renal apical organic anion trans porter 4 function by two PDZ domain-containing proteins. J Am Soc Nephrol 2005, 16:3498-3506.

58. Jutabha $\mathrm{P}$, Anzai $\mathrm{N}$, Endou $\mathrm{H}$, et al:: Interaction of the multivalent PDZ damain protein PDZK1 with type 1 sodiumphosphate cotransporter (NPT1). J Am Soc Nephrol 2005, 16:350A.

59. Kahn AM: Indirect coupling between sodium and urate transport in the proximal tubule. Kidney Int 1989, 36:378384.

60. Roch-Ramel F, Guisan B, Schild L: Indirect coupling of urate and p-aminohippurate transport to sodium in human brush-border membrane vesicles. Am J Physiol 1996, 270: F61-68.

61. Gopal E, Fei YJ, Sugawara M, Miyauchi S, Zhuang L, Martin P, Smith SB, Prasad PD, Ganapathy V: Expression of slc5a8 in kidney and its role in $\mathrm{Na}(+)$-coupled transport of lactate. $J$ Biol Chem 2004, 279:44522-44532.

62. Anzai N, Kanai $\mathrm{Y}$, Endou $\mathrm{H}$ : New insights into renal transport of urate. Curr Opin Rheumatol 2007, 19:151-157.

63. Mardones P, Pilon A, Bouly M, Duran D, Nishimoto T, Arai H, Kozarsky KF, Altayo M, Miquel JF, Luc G, Clavey V, Staels B, Rigotti $A$ : Fibrates down-regulate hepatic scavenger receptor class B type I protein expression in mice. J Biol Chem 2003, 278:7884-7890.

64. Tachibana K, Anzai N, Ueda C, Katayama T, Yamasaki D, Kirino T, Takahashi R, Ishimoto K, Komori H, Tanaka T, Hamakubo T, Ueda Y, Arai H, Sakai J, Kodama T, Doi T: Regulation of the human PDZK1 expression by peroxisome proliferator-activated receptor alpha. FEBS Lett 2008 , 582:3884-3888

65. Halestrap AP, Price NT: The proton-linked monocarboxylate transporter (MCT) family: structure, function and regulation. Biochem J 1999, 343:281-299.

66. Wagner L, Oliyarnyk O, Gartner W, Nowotny P, Groeger M, Kaserer K, Waldhausl W, Pasternack MS: Cloning and expression of secretagogin, a novel neuroendocrine- and pancreatic islet of Langerhans-specific $\mathrm{Ca}^{2+}$-binding protein. J Biol Chem 2000, 275:24740-24751.

67. Farrelly D, Brown KS, Tieman A, Ren J, Lira SA, Hagan D, Gregg R, Mookhtiar KA, Hariharan N: Mice mutant for glucokinase regulatory protein exhibit decreased liver glucokinase: a sequestration mechanism in metabolic regulation. Proc Natl Acad Sci U S A 1999, 96:14511-14516.

68. Shiota C, Coffey J, Grimsby J, Grippo JF, Magnuson MA Nuclear import of hepatic glucokinase depends upon glucokinase regulatory protein, whereas export is due to a nuclear export signal sequence in glucokinase. $J$ Biol Chem 1999, 274:37125-37130.

69. Saxena R, Voight BF, Lyssenko V, Burtt NP, de Bakker PI, Chen H, Roix JJ, Kathiresan S, Hirschhorn JN, Daly MJ, Hughes TE, Groop L, Altshuler D, Almgren P, Florez JC, Meyer J, Ardlie K, Bengtsson Bostrom K, Isomaa B, Lettre G, Lindblad $\mathrm{U}$, Lyon HN, Melander O, Newton-Cheh C, Nilsson P, OrhoMelander M, Rastam L, Speliotes EK, Taskinen MR, Tuomi T, et al:: Genome-wide association analysis identifies loci for type 2 diabetes and triglyceride levels. Science 2007, 316: 1331-1336.

70. Vaxillaire M, Cavalcanti-Proenca C, Dechaume A, Tichet J, Marre M, Balkau B, Froguel P: The common P446L polymorphism in GCKR inversely modulates fasting glucose and triglyceride levels and reduces type 2 diabetes risk in the DESIR prospective general French population. Diabetes 2008, 57:2253-2257

71. Perez-Martinez P, Corella D, Shen J, Arnett DK, Yiannakouris N, Tai ES, Orho-Melander M, Tucker KL, Tsai M, Straka RJ, 
Province M, Kai CS, Perez-Jimenez F, Lai CQ Lopez-Miranda J, Guillen M, Parnell LD, Borecki I, Kathiresan S, Ordovas JM: Association between glucokinase regulatory protein (GCKR) and apolipoprotein A5 (APOA5) gene polymorphisms and triacylglycerol concentrations in fasting, postprandial, and fenofibrate-treated states. Am J Clin Nutr 2009, 89:391-399.

72. Quinones Galvan A, Natali A, Baldi S, Frascerra S, Sanna G, Ciociaro D, Ferrannini E: Effect of insulin on uric acid excretion in humans. Am J Physiol 1995, 268:E1-5.

73. Bakker SJ, Gans RO, ter Maaten JC, Teerlink T, Westerhoff HV, Heine RJ: The potential role of adenosine in the pathophysiology of the insulin resistance syndrome. Atherosclerosis 2001, 155:283-290.

74. Hosoya T, Ueda T, Kamatani N, Nakajima H, Hisatome I, Fujimori S, Yamanaka H, Yamamoto T, Oono I: Guideline for the management of hyperuricemia and gout. Gout Nucleic Acid Metab 2002, 26 (suppl):1-79 [In Japanese].

75. Zhang W, Doherty M, Bardin T, Pascual E, Barskova V, Conaghan P, Gerster J, Jacobs J, Leeb B, Liote F, McCarthy G, Netter P, Nuki G, Perez-Ruiz F, Pignone A, Pimentao J, Punzi L, Roddy E, Uhlig T, Zimmermann-Gorska I: EULAR evidence based recommendations for gout. Part II: Management. Report of a task force of the EULAR Standing Committee for International Clinical Studies Including Therapeutics (ESCISIT). Ann Rheum Dis 2006, 65:1312-1324.

76. Jordan KM, Cameron JS, Snaith M, Zhang W, Doherty M, Seckl J, Hingorani A, Jaques R, Nuki G: British Society for Rheumatology and British Health Professionals in Rheumatology guideline for the management of gout. Rheumatology 2007, 46:1372-1374.

77. Bahn A, Hagos Y, Reuter S, Balen D, Brzica H, Krick W, Burckhardt BC, Sabolic I, Burckhardt G: Identification of a new urate and high affinity nicotinate transporter, hOAT10 (SLC22A13). J Biol Chem 2008, 283:16332-16341.

78. Van Aubel RA, Smeets PH, van den Heuvel JJ, Russel FG: Human organic anion transporter MRP4 (ABCC4) is an efflux pump for the purine end metabolite urate with multiple allosteric substrate binding sites. Am J Physiol Renal Physiol 2005, 288:F327-333.

79. Ichida K, Hosoyamada M, Kimura H, Takeda M, Utsunomiya Y, Hosoya T, Endou $\mathrm{H}$ : Urate transport via human PAH transporter hOAT1 and its gene structure. Kidney Int 2003, 63: 143-155.

80. Bakhiya A, Bahn A, Burckhardt G, Wolff N: Human organic anion transporter 3 (hOAT3) can operate as an exchanger and mediate secretory urate flux. Cell Physiol Biochem 2003, 13:249-256.

81. Gisler $S M$, Pribanic $S$, Bacic $D$, Forrer $P$, Gantenbein A Sabourin LA, Tsuji A, Zhao ZS, Manser E, Biber J, Murer H: PDZK1: I. a major scaffolder in brush borders of proximal tubular cells. Kidney Int 2003, 64:1733-1745.

82. Russel FG, Masereeuw R, van Aubel RA: Molecular aspects of renal anionic drug transport. Annu Rev Physiol 2002, 64: 563-594.

83. Hoque MT, Conseil G, Cole SP: Involvement of NHERF1 in apical membrane localization of MRP4 in polarized kidney cells. Biochem Biophys Res Commun 2009, 379:60-64.

Published: 29 December 2009

doi:10.1186/gm118

(C) 2009 BioMed Central Ltd 